\title{
SUPPORT TO SMALL AND MEDIUM ENTERPRISES - BUSINESS INCUBATORS IN SLOVAKIA
}

\author{
Ol'ga Kašjaková \\ The Slovak University of Technology in Bratislava, Faculty of Civil Engineering, Department of Economics and \\ Management of Building, Radlinského 11, 81368 Bratislava, Slovakia \\ Tel: +421 259274 647, Cellphone: +421903960 139, e-mail: kasjakova@svf.stuba.sk
}

Received 10 February 2004; accepted 29 April 2004

\begin{abstract}
In both developed and developing economies, policies supporting small and medium enterprises are widely promoted as their role for economic and social development is universally recognised. Support programs range from technical assistance to tax incentives, from direct supply of capital to regulatory provisions, training, support to innovation and other types of incentives. One of the mechanisms employed to nurture small firms for more than two decades is „business incubation“.
\end{abstract}

Keywords: business incubator, technological incubator, business incubation, small and medium entrepreneurs,

\section{Introduction}

In today's global economy, it is vital for nations and regions to maintain their competitiveness. A major factor in this is the development of innovative products and services, which in turn depends significantly upon the efficiency of the transfer of technology from academic and research institutions into industry. Indeed, many industrialised nations now talk of a „knowledge-based economy“.

Innovation policy has developed slovly in Slovakia during the transition period. The legal framework for support of innovation is somewhat fragmentary and undeveloped. The necessary economic, social and institutional structures have not yet been sufficiently developed. The incubators will make a meaningful contribution to the development of the enterprise and to the economy in general. They should be the essential vehicle by which potential entrepreneurs can realise their ambitions. They will also enable Slovakia to develop its own indigenous base of higher value added industry and provide a counterbalance to the multinationals who will arrive with EU membership.

\section{Economic Situation of Slovakia and its Regions}

Geographically, Slovakia bridges Western and Eastern Europe (Fig 1). „The Slovak Republic has experienced remarkable progress during the first four years of its independence", declared a group of American experts.

Slovakia can pride itself on industrial heritage with well-developed sectors such as electro-technology, automotive, engineering and wood processing industry, recently also offering new investment possibilities in information technology and strategic services.

The macro-economic results of Slovakia are comparable to the evolution of its neighbouring countries and in numerous areas, Slovakia's economic indicators present better figures than the majority of former Eastern bloc countries.

In spite of the difficult competition from different countries struggling to attract foreign investors, it must be noted that numerous foreign companies have chosen to develop their business activities in Slovakia and that other companies are following their lead. 
In the position of economic progress, Slovakia is in the first half of the candidate states. GDP per inhabitant is around $50 \%$ of the EU average. The most attractive and competitive is the Bratislava region.

Owing to its pro-investment reform policy, the Slovak government succeeded in creating one of the very best investment environments in Europe. Credibility of the reforms has been corroborated by further expansion of already established, satisfied investors as well as by the increased interest of potential investors willing to invest in Slovakia. Competitive advantages of Slovakia include in particular:

$87,6 \%$ of the Slovak population receives higher or secondary education. In Slovakia there are 24 Universities.

The foreign investments are dominant in Bratislava region due to (Fig 2):
- the infrastructure,

- qualified labour force,

- the low costs of production,

- averages of localisation company in administrative centre.

Slovakia's gross domestic product (GDP) has been growing steadily, reaching 3.3 percent in 2001 and projected for 3,6 percent in 2002. The growing domestic demand has been driving the rise, aided by gains in fixed investment. In 2003, the real GDP growth is forecast to rise to $4.1 \%$ and $5 \%$ in 2004 .

Bratislava region reaches an ordinary GDP in EU. Others regions are not so much developed, their GDP is one half from the one of Bratislava. It is related mainly to the big unemployment, low foreign investments and inadequate traffic infrastructure.

Slovakia continues to struggle with a lack of employment opportunity, though the unemployment rate has

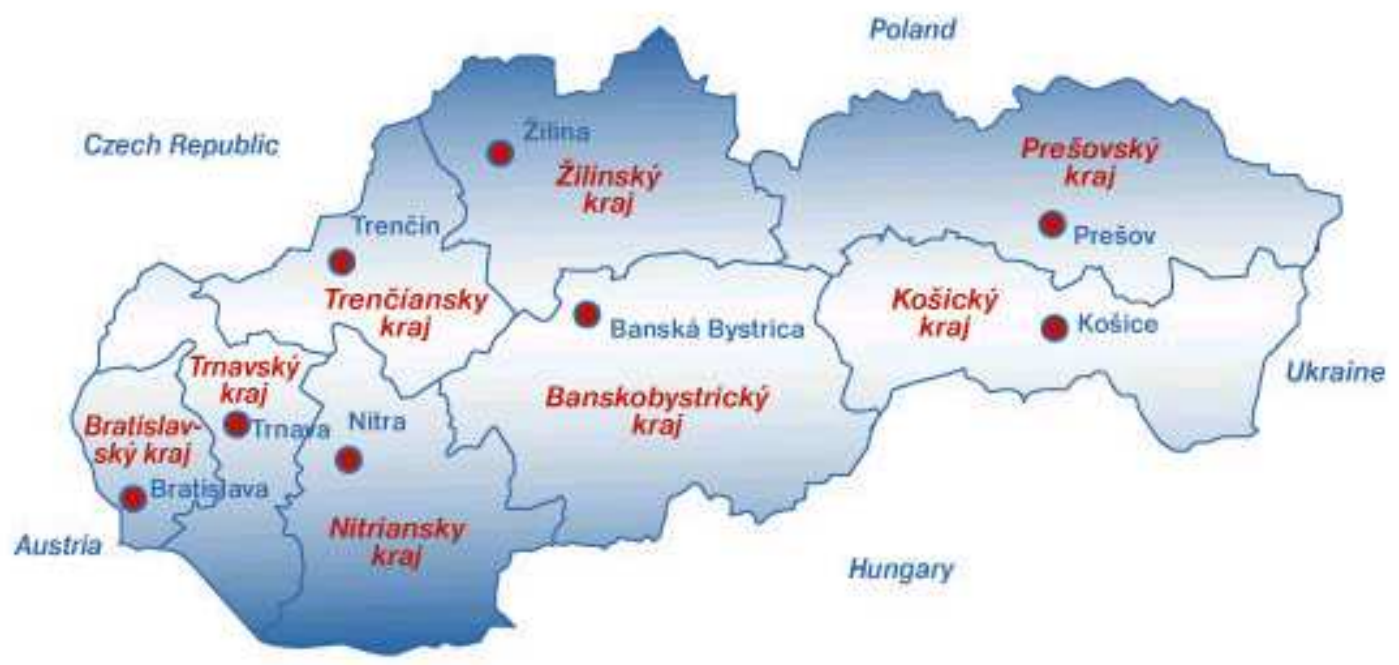

Fig 1. The map of Slovakia and its regions

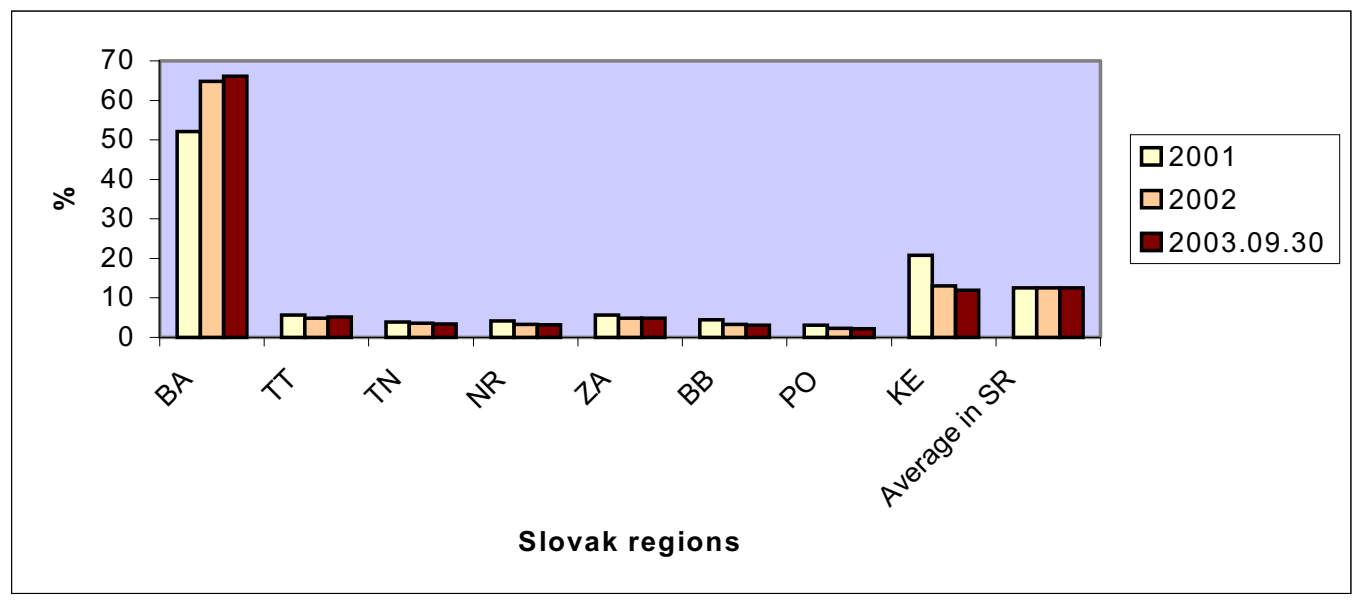

Fig 2. Foreign investments into the company sphere by regions till year 2002 (\%) [1] 
Table 1. Regional GDP in Slovakia in 1996 - 2001 (\%) [2]

\begin{tabular}{|l|c|c|c|c|c|c|}
\hline \multicolumn{1}{|c|}{ Region } & $\mathbf{1 9 9 6}$ & $\mathbf{1 9 9 7}$ & $\mathbf{1 9 9 8}$ & $\mathbf{1 9 9 9}$ & $\mathbf{2 0 0 0}$ & $\mathbf{2 0 0 1}$ \\
\hline Bratislavský & $\mathbf{2 4 , 3}$ & $\mathbf{2 4 , 9}$ & $\mathbf{2 5 , 0}$ & $\mathbf{2 4 , 9}$ & $\mathbf{2 5 , 1}$ & $\mathbf{2 5 , 3}$ \\
\hline Trnavský & 11,2 & 11,0 & 10,7 & 10,8 & 10,8 & 10,3 \\
\hline Trenčiansky & 10,7 & 10,4 & 10,4 & 10,5 & 10,4 & 10,4 \\
\hline Nitriansky & 11,5 & 11,3 & 11,3 & 11,6 & 11,7 & 11,1 \\
\hline Žilinský & 10,4 & 10,5 & 10,5 & 10,4 & 10,4 & 10,5 \\
\hline Banskobystrický & 10,3 & 10,3 & 10,3 & 10,2 & 10,2 & 10,3 \\
\hline Prešovský & $\mathbf{9 , 2}$ & $\mathbf{9 , 1}$ & $\mathbf{9 , 0}$ & $\mathbf{8 , 8}$ & $\mathbf{8 , 8}$ & $\mathbf{8 , 9}$ \\
\hline Košický & 12,4 & 12,5 & $\mathbf{1 2 , 8}$ & 12,8 & 12,6 & 13,2 \\
\hline Slovensko & $\mathbf{1 0 0 , 0}$ & $\mathbf{1 0 0 , 0}$ & $\mathbf{1 0 0 , 0}$ & $\mathbf{1 0 0 , 0}$ & $\mathbf{1 0 0 , 0}$ & $\mathbf{1 0 0 , 0}$ \\
\hline
\end{tabular}

Table 2. Establishment and closing of companies in Slovakia since 1. of January 2002 till 31. of December 2002 [2]

\begin{tabular}{|l|c|c|c|c|}
\hline \multirow{2}{*}{ Region in Slovakia } & \multicolumn{2}{|c|}{ Establishment companies in Slovakia } & \multicolumn{2}{c|}{ Ending companies in Slovakia } \\
\cline { 2 - 5 } & Company & Tradesman & Company & Tradesman \\
\hline Bratislavský & 110 & $\mathbf{2 4 9 7}$ & $\mathbf{9 6}$ & $\mathbf{1 4 2 4}$ \\
\hline Trnavský & 197 & 4160 & $\mathbf{2 7}$ & 1920 \\
\hline Trenčiansky & 100 & 4659 & 55 & 2024 \\
\hline Nitriansky & $\mathbf{2 8 2}$ & 4922 & 26 & $\mathbf{2 7 2 6}$ \\
\hline Žilinský & 148 & $\mathbf{6 3 4 8}$ & 52 & 2510 \\
\hline Banskobystrický & 111 & 4660 & 38 & 2250 \\
\hline Prešovský & $\mathbf{9 1}$ & 6106 & 36 & 2327 \\
\hline Košický & $\mathbf{9 1}$ & 4347 & 55 & 2241 \\
\hline Slovakia & $\mathbf{1 1 3 0}$ & $\mathbf{3 7 6 9 9}$ & $\mathbf{3 8 5}$ & $\mathbf{1 7 4 2 2}$ \\
\hline
\end{tabular}

been slowly falling from the 2001 high of around 21 percent to a current level of 15.4 percent. The current level of the unemployment has been affected by the stricter rules set by the Ministry of labour, social affairs and family. The business or technological incubators and science parks have huge positive influence on unemployment. Is necessary to found mentioned institutions in less developed regions of Slovakia with high educational potential but low employment.

From this figure it is obvious that approximately one half of the established tradesmen are ending. SME are very important to the national economy because their participation on GDP is $35 \%$. They need an urgent help in Slovakia. The National Agency for Development of Small an Medium Enterprises offers support to small and medium enterprises in Slovakia. It operates many activities for the development of enterprises.

\section{Nadsme - an Agency for the Support to „Sme“ in Slovakia}

The National Agency for Development of Small and Medium Enterprises (NADSME) was founded as a joint initiative of the PHARE programme of the European Union and the Government of the Slovak Republic. The main mission of the Agency is to initiate the development and the growth of the existing and newly formed small and medium enterprises in Slovakia. It co-ordinates all activities directed towards providing support to small and medium enterprises, including the financial, at an international, national or local level.

The Agency created the entrepreneurial central network in Slovakia. At present it consists of 13 Regional Advisory and Information Centres (RAIC), 5 Business and Innovation Centres (BIC), 9 First Contact Points (FCP) and 10 Business Incubators (BI). One of the most important RAIC/BIC/FCPs aim is to help to establish the network of small and medium enterprises in particular regions in Slovak Republic by providing advisory, information and educational services. The $\mathrm{RAIC} / \mathrm{BIC} / \mathrm{FCP} / \mathrm{BIs}$ clients are not only the small and medium entrepreneurs but also those who only want to start the business (Fig 3).

The Regional Advisory and Information Centres are non-profit institutions working on the basis of the partnership between the public and private sectors as 

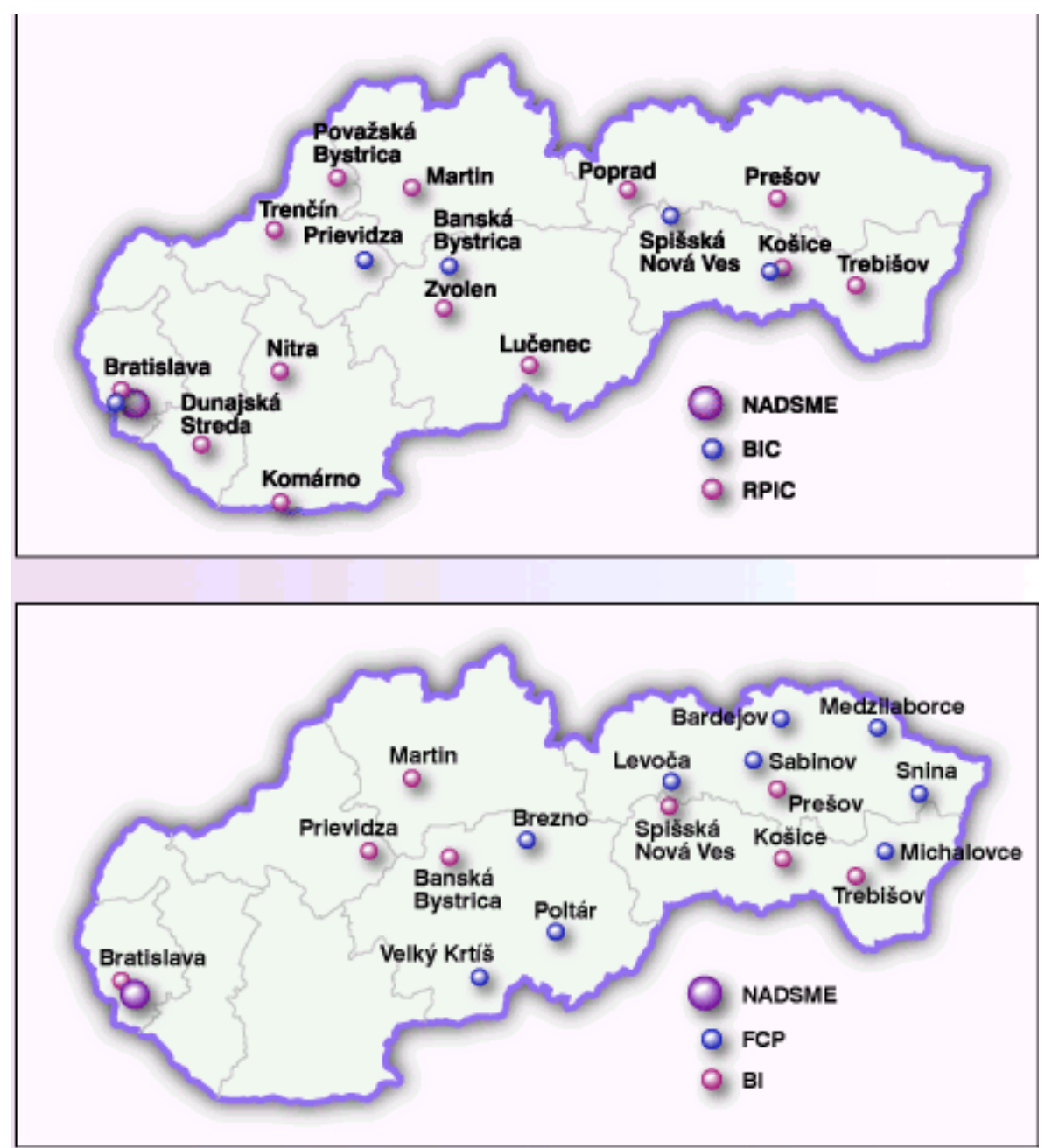

Fig 3. The maps of BIC, RPIC, FCP and BI provided by NADSME

independent regional associations of legal entities. They are funded from Slovak and foreign sources designed to provide support to small and medium enterprises. RAICs provide comprehensive advisory, information and training services, particularly for two target groups:

- starting entrepreneurs who have decided to run their own small or medium-sized business, particularly to the unemployed persons who intend to pursue their business ideas, and,

- active SMEs who need to solve their business problems or are interested in expanding their business further.

RAICs have won themselves a reputation as reliable partners with entrepreneurs who are in need of help in solving of various problems. This is mainly because RAICs:

- are able to assess the chances and risks involved in a business idea,

- prepare business plans in a form which is acceptable to banks and foreign support funds established to prepare business initiatives of SMEs,

- provide consulting services and information in the areas of:

- management,

- marketing,

- taxation,

- legislation.

- seek suitable partners for co-operation, mainly abroad,

- organise participation of Slovak companies in trade fairs,

- organise a comprehensive consulting and training programme for unemployed persons who intend to found their own business. This is done in the co-operation with the regional Labour Offices under the co-ordination of CEPAS Slovakia,

- hold specialised seminars aimed at key areas of business and various topical issues for active entrepreneurs to provide an methodological guidance to the regional development programmes 
Business and Innovation Centres (BIC) are independent corporate bodies-limited liability companies. The main services provided by BICs are:

- preparation of business and marketing plans,

- preparation of loan applications,

- accounting and finance,

- finding partners in the region and abroad,

- to identify foreign sources for the formation of joint ventures,

- legal advice,

- tax and customs consulting,

- book-keeping,

- implementation of quality systems (ISO 9000),

- technological and patents consulting,

- due diligence for projects evaluation and risk financing,

- spin-off consulting.

Besides providing serviciales above mentioned for entrepreneurs they are also oriented towards creating of entrepreneur environment for those firms whose business plans are innovative (launching a new product, service or technology) and work with them for a period of 2 to 3 years. The availability of such $\mathrm{BIC}$ assistance is a subject to the regional preferences. The services provided for clients whose business plans are considered as innovative are:

- identifying innovative projects (brokerage activity),

- preparation of business plan,

- financial management and accounting consulting,

- project financing consulting,

- contacts within the European network of BICs,

- training programmes,

- joint participation at exhibitions and fairs,

- promotion and public relations,

- initiation of co-operation links.

BICs provide newly registered entrepreneurs with the material assistance and serve as ,incubators" for small innovative firms, thereby helping to reduce the inevitable start-up costs.

At the advantageous rates, BICs offer:

- leasing of business premises,

- copying,

- secretarial services,

- printing and binding,

- fax and telephone services.

At present there are 9 business incubators in Slovakia:

- Business incubator Prievidza, Martin-Flemish business and innovation centre Martin, Business incubator and technological centre Banská Bystrica, Technological incubator Prešov, Tech- nological incubator Košice, Technological incubator Bratislava, Incubator Rožňava, Incubator Spišská Nová Ves, Business incubator Rožňava, Technological incubator Žilina.

Several of them are focused on the high-tech:

- Technological incubator Bratislava, Business incubator and technological centre Banská Bystrica, Technological incubator Košice, Technological incubator Prešov, Business incubator Prievidza, Technological incubator Žilina.

\section{Experience of Business Incubation}

The next chapter will describe the experiences of business incubators in abroad. The term „Business incubators" are not very usually and known in Slovakia. Therefore this chapter deals with the concept of business incubation, its advantages for SME, the region and the government. It is very important to understand the support process for SME.

\section{Business incubation's beginnings}

U.S. business incubators come into being in the 1970s - although the oldest of all began in Batavia, NY, in 1959. They evolved from three simultaneous movements. The first was the attempt to use old, abandoned factory buildings in distressed areas, the second was begun as an experiment funded by the National Science Foundation to foster entrepreneurship and innovation at major universities. The third movement arose from initiatives of several successful individual entrepreneurs or groups of investors that sought to transfer their own new venture experiences to new companies in an environment conducive to successful technological innovation and commercialisation [3].

Today, there are about 1,000 business incubators in North America, up from only 12 in 1980 . There are about 4,000 business incubators world-wide.

\section{The concept of business incubation}

Business incubation can have several definitions and approaches. According to the national Business Incubators Association (NBIA), „Business incubation catalyses the process of starting and growing companies, providing entrepreneurs with the expertise, networks and tools they need to make their ventures successful. Incubation programs diversify economies, commercialise technologies, create jobs and build wealth" [3]. 
Business incubation is a dynamic process of business enterprise development. Incubator nurture young firms, helping them to survive and grow during the start-up period when they are most vulnerable. Incubators provide hands-on management assistance, access to financing and orchestrated exposure to critical business or technical support services. Most also offer entrepreneurial firms shared office services, access to equipment, flexible leases and expandable space - all under one roof.

A business incubator is usually a property with small work units which provides a supportive environment to entrepreneurs at start-up and during the early stages of businesses. Incubators provide an entrepreneurial and learning environment, ready access to mentors and investors, and visibility in the marketplace [4].

Incubators are generally characterised by some relevant features, which generally include [5]:

- A managed work space providing shared facilities, advisory, training and financial services, and a nurturing environment for tenant companies;

- A small management team with core competencies;

- Selection of start-up companies entering the incubator, 20 to 25 in the average, to be graduated generally after 3 years.

Incubator models may vary according to:

- their mandate (for-profit or not-for-profit),

- the type of sponsorship they have (publicprivate-mixed),

- their focus (mixed-use niche). The most frequent types of niche incubators are related to technology (technology incubators) and bio-technology (bio- incubators). More recently, and especially in the U.S., a new generation of dot.com incubators emerged, although their number considerably decreased after the so-called ,internet bubble“ in early 2000 .

Incubation programs may also have a wide range of goals, including (Fig 4):

- economic development and generation of new jobs,

- marketing of research investments,

- property venture/real estate development,

- creation of entrepreneurship in transition economies,

- opportunities for national immigrants and nationals graduating abroad,

- development of export production.

An incubation program's main goal is to produce successful graduates - usinesses that are financially viable and free-tanding when they leave the incubator usually in two to three years. Thirty percent of incubator clients typically graduate each year.

Like venture capitalists, incubators impose selection criteria upon prospective clients. Some accept a mix of industries, but others concentrate on industry niches. Incubator clients are at the forefront of developing new and innovative technologies - creating products and services that improve the quality of our lives.

Government subsidies for well-anaged business incubation programs represent strong investments in local and regional economies. Consider these returns:

- Research has shown that, for every $\$ 1$ of

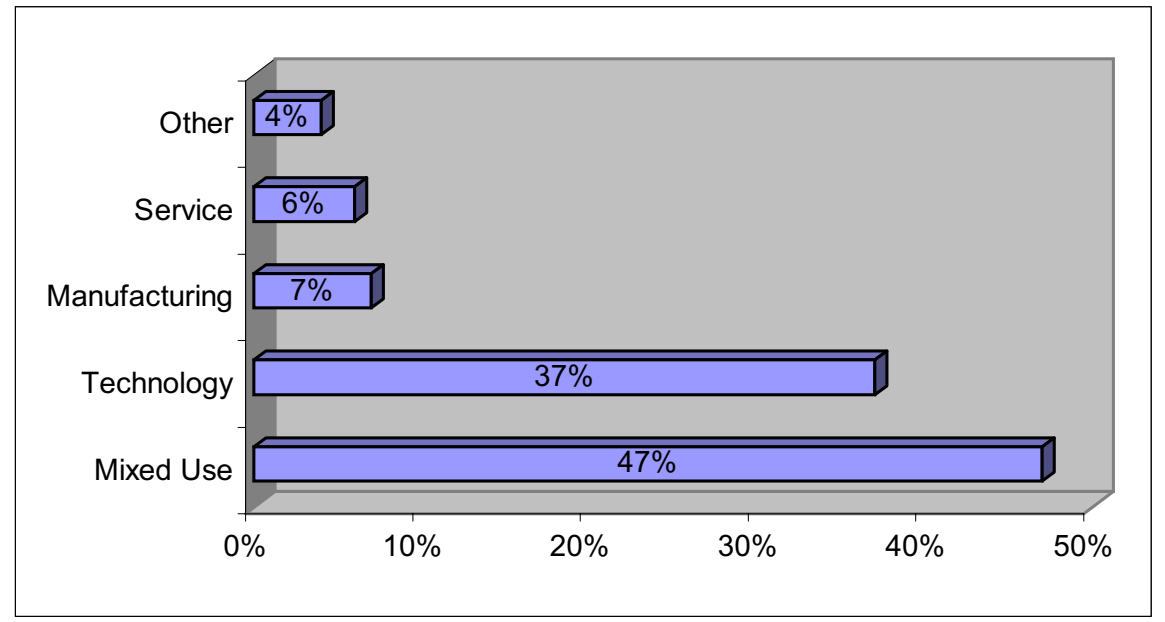

Fig 4. According to NBIA research, incubation programs may be classified as follows

* May not add up to 100 percent due to rounding

** „Other“ responses included community revitalization incubation programs, incubation programs for Web-related businesses, and „other“ 
estimated public investment provided the incubator, clients and graduates of NBIA member incubators generate approximately $\$ 30$ in local tax revenue alone.

- NBIA members have reported that 84 percent of incubator graduates stay in their communities and continue to provide a return to their investors.

- Publicity supported incubators create jobs at a cost of about $\$ 1,100$ each, whereas other publicly supported job creation mechanisms commonly cost more than $\$ 10,000$ per job created.

The incubators's contribution to the local and regional economies is eminent. Incubator graduates create jobs, revitalise neighbourhoods, and commercialise new technologies, thus strengthening local, regional, and even national economies. Every 50 jobs created by incubator client generate approximately 25 more jobs in the same community. Business incubators reduce the risk of small business failures. Historically, NBIA member incubators have reported that 87 percent of all firms that have graduated from their incubators are still in business [3].

\section{Technological Incubators in Slovakia - Research Based Spin off Method}

SME support programme Research Based Spin Off Method launched the Slovak ministry of Economy for the period $2001-04$.

The research based spin off method of the enterprise development has a number of advantages [6]:

- facilitates potential entrepreneurs currently attached to a university or institute to commercialise an idea or concept,

- makes the university or institute more relevant to the wider economy and the general public,

- adds to capacity building,

- raises the level of technology in use in the country as a whole,

- increases added value,

- creates employment,

- aids the transition to a knowledge based society.

Companies based in the technological incubator (T.I.) are more attractive to seed capital and venture capitalists because they have a much higher success rate (Fig 5). Capitalists will always want to minimise their financial risk. Thus start up companies based in T.I.'s are more likely to be in a position to raise capital which further adds to the relevance and strength of the concept of T.I.'s.

In the SME support programme launched by the Slovak ministry of Economy for the period 2001 - 04 the following criteria are set out for applications by start up businesses from the seed and venture capital found.

Start up project of new the entrepreneur should meet the following criteria [6]:

- to be top in innovation, in technology, to support energy, or cost saving, in environment,

- to be approved by the committee composed by Ministry of Economy, NADSME, Ministry of Finance, academic and technological institutions representatives. The incubator's managing director is to submit the project.

Procedure for the support applying in the appropriate fiscal year:

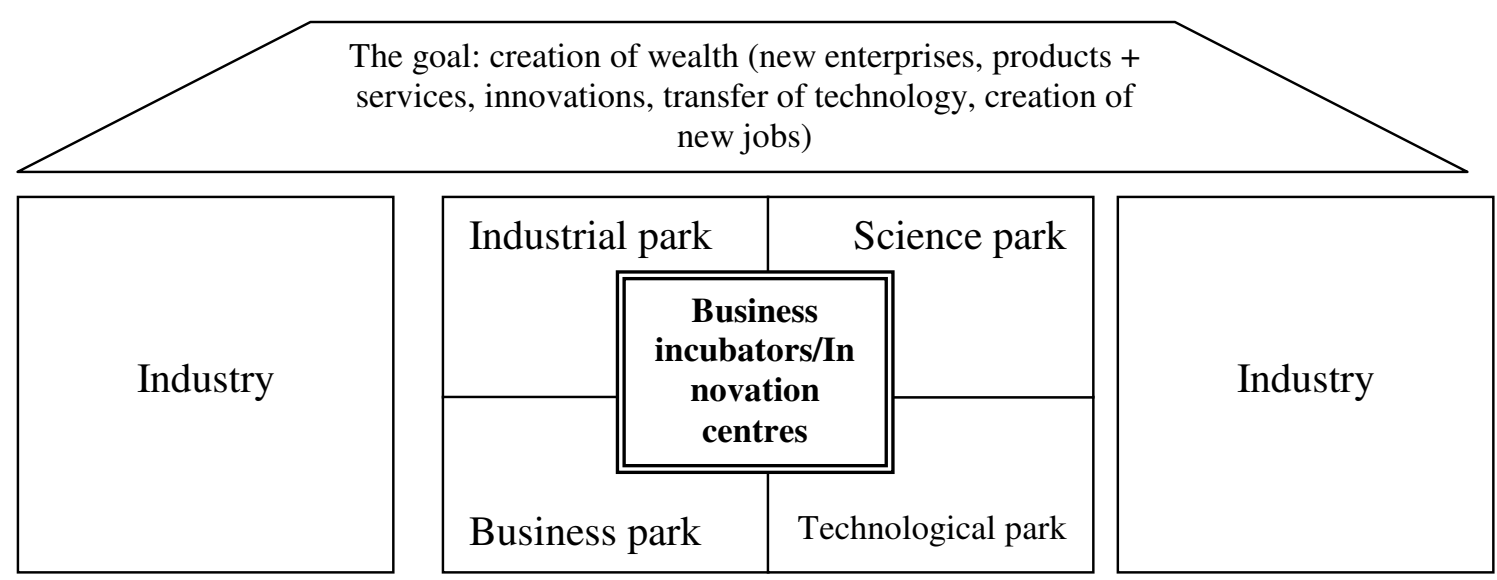

Basis: Regional potential

Fig 5. Relationship between business incubator and his surroundings 
- incubator will apply for the support at NADSME submitting its forecasted income statement for the NADSME approval,

- incubators projects are to be submitted by the appropriate incubator's manager to NADSME for completeness,

- the decision making committee which will approve or disapprove the application and the support amount (up to SKK 5 million).

Projects: financial support is to be provided based on agreement between NADSME or investor and the appropriate applicant or between incubator and applicant.

\section{Technological Incubator in Žilina}

It is one of the best operated incubators in Slovakia with great experiences and effort to improve and extend its services.

In 1999 the Industry Liaison Office (ILO) was founded in Žilina. Science-echnological park (STP) in Žilina has emerged in September 2001. ILO in Žilina was reconstructed to STP. One important part of the activity in STP in Žilina is the technological incubator. The building of the technological incubator is undergoing restoration. At present 9 entrepreneurs has a seat there that are focused on IT and computers. After restoration there will be up to 35 entrepreneurs. Most of them are former students of the Technology University in Žilina. STP and its technological incubator is located in campus of the Technology University in Žilina.

\section{Services offered in the technological incubator in Žilina}

Basic services included in rent [7]:

- energy (electric power, heat energy and water),

- Internet connection,

- telephone connection,

- common places (entrance, rest room, kitchen),

- electric security of common place and entrance,

- parking,

- postal services,

- access to information and databases of Science park Žilina,

- access to library of the Technology University in Žilina.

Services in the technological incubator in Žilina offered excluding the rent [7]:

- cleaning of offices,

- electric security of offices,

- use of meeting rooms of the Technology
University in Žilina,

- use of fax, printer, copier, scan machine,...,

- use of university canteen and snack bar,

- services of telephone central.

Administrative services:

- formulation of the business plan,

- formulation of the application for the financial support (government, EU, banks,...),

- economic consultancy,

- book-keeping,

- legal consultancy,

- marketing activity (marketing research, webpresentation, publicity promotion),

- translation, search,....

Technical services:

- procurement of university potential - gauge, research, calculation, machine, laboratory, ....

Business support services [6]:

The tenants in the T. I. are likely to have technical or academic backgrounds and could be lacking of business skills. They need an access to the business skills training and it is envisaged that these services will be provided by other agencies from their own budgets. The manager of the T.I. would act in a liaison capacity.

Type of services which the clients might require would be:

- assistance with registering a patent,

- access to funding including the Seed Capital Company,

- specialist technical information,

- technology transfer opportunities,

- general opportunity to be able to „talk through“ a problem or get a second opinion.

\section{Conclusion}

The business incubator may be a very appropriate and useful tool for the development of private companies in the changing Slovak economy. The incubators should be created in major cities, in municipalities where a specific knowledge base has been created through industrial or education development, and which hold promise as a resource for entrepreneurial initiatives.

This paper has been written to serve two major purposes: to explain business incubators to those who may not be familiar with them and to suggest how this device might help meet the needs of the emerging market economy and how to help to SME in Slovakia. Experience has shown that each of the emerging democracies in the region will need to design and 
tailor its own institutions, and it is certain this will apply to business incubators as well.

Business or technological incubators and science parks help start-ups, decrease unemployment, put graduates of universities into effect, support of economic progress, increase wealth of the region, production of high added value and transfer knowledge to practice. Is necessary to found mentioned institutions in less developed regions of Slovakia with high educational potential but low employment. The government offers SME an support programme and Slovakia has occasions, to use the structural founds for this purpose.

\section{References}

1. Slovak Investment and Trade Development Agency, $<\mathrm{http}$ // www.sario.sk> [viewed at January 2004].

2. Statistical Office of the Slovak Republic, <http:/ www.statistics.sk> [viewed at January 2004].

3. National Business Incubation Association, The history of Business Incubation, What is Incubator, Business Incubation FAQ, <http:/www.nbia.org/resource_center/ what_is/beginnings_of_inc/index.php $>$ [viewed at July 2004].

4. Science Parks, Business Incubators and Clusters, Briefing sheet 18, British Council. December 2002.

5. Scaramuzzi, E. Incubators in Developing Countries: Status and Development Perspectives The World Bank, Washington DC. May 2002.

6. The National Agency for Development of Small and Medium Enterprises (NADSME), Operational Manual for Technological Incubators. April 2004.

7. Science park in Žilina, Project: Technological incubator. May 2003. 